Research Article

www.ijrap.net

\title{
WOUND HEALING ACTIVITY OF ALCOHOLIC EXTRACT OF SOLANUM ERIANTHUM D.DON IN EXCISION AND INCISION METHOD
}

Ch. Sudha Bhargavi ${ }^{1 *}$, Vrushabendra Swamy ${ }^{2}$, Syed Bilal ${ }^{2}$, Ushasri. S ${ }^{1}$, Ranjith Kumar. J ${ }^{1}$

${ }^{1}$ Sri Siddhartha Pharmacy College, Nuzvid, Krishna District, Andhra Pradesh, India

${ }^{2}$ Gautham College of Pharmacy, R.T Nagar, Bangalore, Karnataka, India

Received on: 07/10/12 Revised on: 30/11/12 Accepted on: 14/12/12

*Corresponding author

E-mail: sudhabhargavipharma@gmail.com

DOI: $10.7897 / 2277-4343.04143$

Published by Moksha Publishing House. Website www.mokshaph.com

All rights reserved.

\section{ABSTRACT}

Solanum erianthum D. Don is an unarmed shrub or small tree with dense indumentums of soft stellate hairs. Leaves are simple, ovate-elliptical; margin entire or slight wavy, base rounded to cuneate, and apex acute to acuminate. The leaves have been extensively used for leucorrhoea, piles, hemorrhoids, scrofula, headache, vertigo, digestive troubles and for wound healing purposes. Wistar albino rats of either sex weighing between 200 and $220 \mathrm{~g}$ were topically treated with extract formulated in gel $(10 \%$ and $20 \%)$ which was applied once daily in excision and incision wound model. Rats of standard groups were treated with $5 \% \mathrm{w} / \mathrm{w}$ Povidone-Iodine ointment topically. The percentage of wound contraction was increased, epithelization period was decreased and wound breaking strength was increased with topical application of AESE (Alcoholic Extract of Solanum erianthum) gel in excision and incision wound model. The experimental data revealed that the AESE displayed remarkable wound healing activity thus supports its traditional use.

Key words: Solanum erianthum D.Don, wound healing, AESE gel

\section{INTRODUCTION}

Many medicinal plants are claimed to be useful for wound healing in the traditional system of medicine. These plant remedies are used since ancient time even if the mechanism of action and efficacy of very few of them have been evaluated scientifically ${ }^{1}$. Solanum erianthum D.Don Family-Solanaceae is an unarmed shrub or small tree up to $4-10 \mathrm{~m}$ tall with a dense of soft stellate hairs, stem up to $20 \mathrm{~cm}$ in diameter leaves simple, ovateelliptical, margin in entire or slightly wavy, base rounded to cuneate, apex acute to acuminate. Adding to the taxonomic confusion is the fact that S.erianthum has been extensively referred to as S.verbascifolium L. which actually proved to be identical with a South American species $^{2}$. S.erianthum is a small tree. S.erianthum has been used as a traditional medicine for treating inflammatory diseases, burns and wounds. Decoction of the root were used for body pains, vertigo and urinary troubles ${ }^{3-5}$. Leaves were given in vaginal discharges. The leaves of S.erianthum have been reported as anti-malarial, anti-cholinergic ${ }^{6,7}$ and burn wound healing ${ }^{19}$. The present study was carried out to determine effect of alcoholic extract of Solanum erianthum leaves on wound healing activity in rats by excision and incision wound healing models.

Discontinuity or break in the surface of the epithelium is called wound. Wound and its management is one of the major problems in the world. The wounds can be caused due to physical, chemical and biological agents. Wound can be classified based on their etiology, lasting period, morphological characters etc. Later the color code concept was used where in the wounds were classified as red yellow or black. Based on the nature and depth wounds can be classified as:
- Closed wounds: i.e. contusions, abrasions, and hematoma

- Open wounds: i.e. incised, lacerated, penetrating and crushed

Depending on the intensity of the wound they can be termed as (a) simple wound: here the damage is only to the skin. (b) Complex wound: the wound involves the underlying tissues, tendons etc. Wound healing is a complex and dynamic process with the wound environment and keep changing with the changing health status of the individual. ${ }^{8}$ Wound healing is a complex phenomenon, involving a number of well-orchestrated processes, including regeneration of parenchyma cells, migration and proliferation of both parenchymal and connective tissue cells, synthesis of ECM (extracellular matrix) proteins, remodeling of connective tissue (C.T.) and parenchymatous components and collagenisation and acquisition of wound strength. ${ }^{9}$

Healing of wound

Healing of wound can occur by

First or Primary Intention: This is seen when the wound is a clean incised wound. Healing proceeds rapidly with early closure of wound. There are several overlapping stages in the repair process.

Inflammation: The cut surfaces become inflamed, blood clot and cell debris fill the gap between them in the first few hours. Phagocytes and fibroblasts migrate in to the blood clot:

- Phagocytes begin to remove the clot and cell debris stimulating fibroblast activity

- Fibroblasts secrete collagen fibers which begin to bind the surface together. ${ }^{10}$

Proliferation: There is proliferation of epithelial cells across the wound, through the clot. The epidermis meets and grows upwards until the full thickness is restored. The 
clot above the new tissue becomes the scab and separates after 3 to 10 days. Granulation tissue, consisting of new capillary buds, phagocytes and fibroblasts, develops, invading the clot and restoring the blood supply to the wound. Fibroblasts continue to secrete collagen fibers as the clot and any bacteria are removed by phagocytosis.

Maturation: The granulation tissue is replaced by fibrous scar tissue. Rearrangement of collagen fibers occurs and the strength of the wound increases. In time, the scar becomes less vascular, appearing after a few months as a fine line. The channels left when stitches are removed, heal by the same process.

Secondary Intention: This is in the case where the wound edges are separate and there is tissue loss and sometimes the wound may be infected. Rapid closure of the wound is not possible. Therefore this leads to an ugly scar and sometimes may cause limitation of movement.

Inflammation: This develops on the surface of the healthy tissue and separation of necrotic tissue begins, mainly due to the action of phagocytes in the inflammatory exudate.

Proliferation: This begins as granulation tissue, consisting of capillary buds, phagocytes and fibroblasts, develops at the base of the cavity. It grows toward the surface, probably stimulated by macrophages. Phagocytes in the plentiful blood supply tend to prevent infection of the wound by ingestion of bacteria after separation of the slough. Some fibroblasts in the wound develop a limited ability to contract, reducing the size of the wound and healing time. When granulation tissue reaches the level of the dermis, epithelial cells at the edges proliferate towards centre.

Maturation: This occurs as scar tissue replaces granulation tissue, usually over several months until the full thickness of the skin is restored. The fibrous scar tissue is shiny and does not contain sweat glands, hair follicles or sebaceous glands.

\section{MATERIALS AND METHODS Plant material}

Leaves of solanum erianthum.D.Don were collected from the local area of Bangalore, Karnataka, India during November 2010 and were authenticated by Dr. Shiddamallaya N, botanist of National Ayurveda Dietetics Research Institute, Bangalore, Karnataka, India. The voucher No: Drug authentication/ SMPU/ NADRI/ BNG/ 2010-11/840 (RRCBI-Mus/06).

\section{Preparation of the extract}

Leaves of solanum erianthum.D.Don were dried in shade and powdered. The powdered materials were extracted with $70 \%$ ethanol using soxhelt extraction apparatus. This ethanol extract was then concentrated and dried under reduced pressure. The semisolid mass (ethanol free) thus obtained was used for the experiment.

\section{The preliminary phytochemical analysis}

The alcoholic extract was tested qualitatively for various plant constituents according to standard methods. ${ }^{11}$

\section{Animals}

Wistar albino rats of either sex weighing 150-200 $\mathrm{g}$ and female albino mice weighing 20-25 g were used in this study. They were procured from Sri Venkateshwara Enterprises, Bangalore. The animals were acclimatized for ten days under laboratory conditions. They were housed in polypropylene cages and maintained $27^{\circ} \mathrm{C} \pm$ $2^{\circ} \mathrm{C}$, relative humidity $65 \pm 10 \%$ under 12 hours light / dark cycle. The animals were fed with rodent pellet diet (Amrut Laboratory animal feeds, Pranav Agro Industries Ltd, Sangli, India) and water ad libitum. All the studies conducted were approved by the Institutional Animal Ethical Committee (IAEC) of Gautham College of Pharmacy, Bangalore, India (GCP-IAEC/006/5/2010) according to prescribed guidelines of Committee for the Purpose of Control and Supervision of Experiments on Animals (Reg No: 491/01/c/CPCSEA), Govt. of India.

\section{Selection of doses}

For assessment of excision and incision ${ }^{12}$ wound healing activity extracts were formulated as a gel. Ethanol extract of S.erianthum (1g) was mixed with $9 \mathrm{~g}$ of sodium alginate with $100 \mathrm{ml}$ of distilled water to get $10 \%(\mathrm{w} / \mathrm{w})$ gel. Same procedure was followed to prepare $20 \%$ (w/w) gel.

\section{Skin Irritation Studies}

The rabbit ${ }^{13}$ was shaved the skin in three different position of dorsal side, each about $500 \mathrm{~mm}^{2}$. The rabbit was kept in rabbit holder and the $1^{\text {st }}$ area was kept as control, to which vehicle was applied. $2^{\text {nd }}$ area was applied with $10 \%$ AESE gel. The $3^{\text {rd }}$ area treated with $20 \%$ AESE gel. (Table 3)

\section{In Vivo Wound Healing Activity}

Excision wound model

Animals were divided in to four groups, each group consisting of 6 rats. $^{14,15}$ (Table 4,5 )

Group I: Received no treatment and served as control Group II: Received application of standard drug ointment i.e. Povidone-Iodine $(5 \% \mathrm{w} / \mathrm{w})$

Group III: Received application of 10\% w/w AESE which considered as low dose.

Group IV: Received application of $20 \%$ w/w AESE which considered as high dose.

AESE: Alcoholic Extract of Solanum erianthum

Under light ether anaesthesia an impression of $500 \mathrm{sq} \mathrm{mm}$ was made on the shaved back of the rat as described in Morton and Malone. The skin of the impressed area was excised carefully. Animals are kept in separate cages. The day on which wound was made consider as day'0' (Zero).

Drugs were topically applied once a day till complete of epitheliazation, starting from day of excision.

The progressive changes in wound area were monitored metrically by tracing the wound margin on graph paper on day of creating wound and subsequently by $2^{\text {nd }}, 4^{\text {th }}, 6^{\text {th }}$ $, 8^{\text {th }}, 10^{\text {th }}, 12^{\text {th }}, 14^{\text {th }}, 16^{\text {th }}, 18^{\text {th }}, 20^{\text {th }}$ and $22^{\text {nd }}$ days post wounding. Number of days required for falling of scab without any residual raw wound, gave the period of epitheliazation.

\section{Percentage wound closure}

(Initial area of Wound - $\mathrm{N}^{\text {th }}$ day area of wound) Percentage Wound Closure $=$ (Initial area of Wounds)

Incision wound model

Animals were divided in to four groups, each group consisting of 6 rats. ${ }^{16,17}$ (Table 6)

Group I: Received no treatment and served as control Group II: Received application of standard drug ointment i.e. Povidone-Iodine $(5 \% \mathrm{w} / \mathrm{w})$ 
Group III: Received application of 10\% w/w AESE which considered as low dose.

Group IV: Received application of $20 \%$ w/w AESE which considered as high dose.

AESE: Alcoholic Extract of Solanum erianthum

The incision wound model was studied. Under light ether anesthesia the animal was secured to operation table in its natural position. One paravertebral straight incision of 6 $\mathrm{cm}$ was made on either side of the vertebral column with the help of scalpel blade. Wounds were cleaned with $70 \%$ alcohol soaked with cotton swabs. They were kept in separate cages. The extract was applied at a dose of $10 \%$ and $20 \% \mathrm{w} / \mathrm{w}$ gel for 10 days. All the sutures were removed on the $9^{\text {th }}$ post wounding day. On tenth day the tensile strength was measured by continuous constant water supply technique.

\section{Measurement of Wound Breaking Strength of incised wounds}

Measurement of wound breaking strength was performed with certain modifications. A board was placed on the table, on which the anaesthetized animal was made to lie on its abdomen. Two clamps were clamped on either sides of healed wound at a distance $0.5 \mathrm{~cm}$. The left clamp was fastened tightly to stand by means of thread. The right clamp was connected to a leak proof polythene container through a pulley, by means of a thread. A reservoir containing water was placed at a suitable height and connected to a polythene bag by means of a rubber tube. The position of the board was adjusted so that, the polythene bag was hanging freely. Water was added to polythene bag rapidly at constant rate from the reservoir until the wound opened. Amount of water in polythene bag was measured (in $\mathrm{ml}$ ) and was considered as tensile strength of the wound.

\section{Statistical analysis}

The relative wound area results were compared using one way analysis of variance (ANOVA) followed by Dunnet's tests. $^{18} P$-values less than 0.05 were considered as indicative of significance.

\section{RESULTS}

\begin{tabular}{|c|c|c|} 
Table 1: Percentage yield of AESE \\
\begin{tabular}{|c|c|c|}
\hline Solvent & Colour and Consistency & Percentage yield \\
\hline $70 \%$ hydro alcohol & Green and sticky & $13.30 \%$ \\
\hline
\end{tabular}
\end{tabular}

Table 2: Preliminary Phytochemical Screening of AESE

\begin{tabular}{|c|c|}
\hline Phytochemical constituents & $70 \%$ hydro alcoholic extract \\
\hline Carbohydrates & + \\
\hline Steroids & + \\
\hline Glycosides & + \\
\hline Flavonoids & + \\
\hline Alkaloids & + \\
\hline Tannins & \\
\hline Triterpinoids & + \\
\hline Saponins & + \\
\hline Proteins & \\
\hline
\end{tabular}

Both the $10 \%$ and $20 \%$ doses of AESE gel does not showed any type of irritation, inflammation and redness.

Table 3: Results of Skin Irritation Study
\begin{tabular}{|c|c|c|}
\hline Group & Sign & Score \\
\hline Control & & 0 \\
\hline $10 \%$ AESE & Not noticeable redness and inflammation & 0 \\
\hline $20 \%$ AESE & Not noticeable redness and inflammation & 0 \\
\hline
\end{tabular}

A significant decrease in period of epitheliazation was observed after 10\% AESE and 20\% AESE application. Treatment with Povidone-Iodine also significantly reduced period of epitheliazation as compared with control group. At the same time $10 \%$ and $20 \%$ AESE and Povidone-Iodine also decreased the wound contraction $(50 \%)$ as compared with control.

Table 4: Effect of leaf extract of S.erianthum on excision wound [Wound Area $\left(\mathbf{m m}^{2}\right)$ ]

\begin{tabular}{|c|c|c|c|c|c|c|c|c|c|c|c|c|}
\hline \multirow[t]{2}{*}{ Group } & \multicolumn{11}{|c|}{ wound contraction on } & \multirow{2}{*}{$\begin{array}{l}\text { Epitheliazation } \\
\text { time (Days) }\end{array}$} \\
\hline & $\begin{array}{l}2^{\text {nd }} \\
\text { Day }\end{array}$ & $\begin{array}{c}4^{\text {th }} \\
\text { Day }\end{array}$ & $\begin{array}{c}6^{\text {th }} \\
\text { Day }\end{array}$ & $\begin{array}{c}8^{\text {th }} \\
\text { Day }\end{array}$ & $\begin{array}{l}10^{\text {th }} \\
\text { Day }\end{array}$ & $\begin{array}{l}12^{\text {th }} \\
\text { Day }\end{array}$ & $\begin{array}{l}14^{\text {th }} \\
\text { Day }\end{array}$ & $\begin{array}{l}16^{\text {th }} \\
\text { Day }\end{array}$ & $\begin{array}{l}18^{\text {th }} \\
\text { Day }\end{array}$ & $\begin{array}{l}20^{\text {th }} \\
\text { Day }\end{array}$ & $\begin{array}{l}21^{\text {st }} \\
\text { Day }\end{array}$ & \\
\hline $\begin{array}{c}\text { A } \\
\text { Control }\end{array}$ & $\begin{array}{c}385.0 \pm \\
6.19\end{array}$ & $\begin{array}{c}330.0 \pm \\
5.77\end{array}$ & $\begin{array}{c}260 \pm \\
7.30\end{array}$ & $\begin{array}{c}210.8 \pm \\
8.20\end{array}$ & $\begin{array}{c}138.5 \pm \\
12.07\end{array}$ & $\begin{array}{c}96.5 \pm \\
5.22\end{array}$ & $\begin{array}{c}69 \pm 13 . \\
12\end{array}$ & $\begin{array}{c}50.83 \pm \\
12.67\end{array}$ & $\begin{array}{c}28.33 \pm \\
9.7\end{array}$ & $\begin{array}{l}10.5 \\
\pm 4.7\end{array}$ & 00 & $9.167 \pm 0.40$ \\
\hline $\begin{array}{c}\text { B } \\
\text { Standard } \\
\text { Povidine-Iodine }\end{array}$ & $\begin{array}{c}356.7 \pm \\
10.5\end{array}$ & $\begin{array}{c}288.8 \pm \\
8.90\end{array}$ & $\begin{array}{c}213.7 \pm \\
2.66\end{array}$ & $\begin{array}{l}125 \pm \\
6.19\end{array}$ & $\begin{array}{c}48.67 \pm \\
5.01\end{array}$ & $\begin{array}{c}36.5 \pm \\
4.63\end{array}$ & $\begin{array}{c}22.67 \pm \\
4.31\end{array}$ & $\begin{array}{c}13.17 \pm \\
2.37\end{array}$ & $\begin{array}{c}3.66 \pm \\
1.68\end{array}$ & 00 & 00 & $8.33 \pm 0.21$ \\
\hline $\begin{array}{c}\mathrm{C} \\
10 \% \mathrm{AESE} \\
\end{array}$ & $\begin{array}{c}316.7 \pm \\
4.21 \\
\end{array}$ & $\begin{array}{c}231.7 \pm \\
13.02 \\
\end{array}$ & $\begin{array}{c}161.7 \pm \\
13.27 \\
\end{array}$ & $\begin{array}{c}88.33 \pm \\
11.08 \\
\end{array}$ & $\begin{array}{c}37.33 \pm \\
9.26 \\
\end{array}$ & $\begin{array}{c}29.67 \pm \\
7.72 \\
\end{array}$ & $\begin{array}{c}19.83 \pm \\
6.86 \\
\end{array}$ & $\begin{array}{c}8.66 \pm \\
2.91 \\
\end{array}$ & 00 & 00 & 00 & $7.50 \pm 0.22$ \\
\hline $\begin{array}{c}\text { D } \\
20 \% \text { AESE }\end{array}$ & $\begin{array}{c}321.0 \pm \\
5.13\end{array}$ & $\begin{array}{c}263.8 \pm \\
8.44\end{array}$ & $\begin{array}{c}164.8 \pm \\
9.44\end{array}$ & $\begin{array}{l}90.17 \pm \\
9.57\end{array}$ & $\begin{array}{c}37.83 \pm \\
5.9\end{array}$ & $\begin{array}{c}29.17 \pm \\
4.48\end{array}$ & $\begin{array}{c}12.33 \pm \\
2.89\end{array}$ & $\begin{array}{c}4.16 \pm \\
1.61\end{array}$ & 00 & 00 & 00 & $7.33 \pm 0.21$ \\
\hline
\end{tabular}

Values are mean \pm SEM (n-6) one way ANOVA followed by Dunnet's test where * represents significant at $<0.05, * *$ represents highly significant at $\mathrm{p}<0.01, * * *$ represents very significant at $\mathrm{p}<0.001$. 
Ch. Sudha Bhargavi et al / IJRAP 4(1), Jan - Feb 2013

Table 5: Effect of leaf extract of S.erianthum on excision wound (\% Wound closure)

\begin{tabular}{|c|c|c|c|c|}
\hline Day & Group I & Group II & Group III & Group IV \\
\hline 0 & 0 & 0 & 0 & 0 \\
\hline 2 & $13.74 \%$ & $24.09 \%$ & $27.98 \%$ & $27.38 \%$ \\
\hline 4 & $26.03 \%$ & $36.00 \%$ & $42.25 \%$ & $40.03 \%$ \\
\hline 6 & $41.78 \%$ & $47.28 \%$ & $63.17 \%$ & $62.72 \%$ \\
\hline 8 & $52.80 \%$ & $71.73 \%$ & $79.91 \%$ & $79.53 \%$ \\
\hline 10 & $69.50 \%$ & $88.97 \%$ & $91.51 \%$ & $88.61 \%$ \\
\hline 12 & $83.97 \%$ & $91.64 \%$ & $93.25 \%$ & $93.38 \%$ \\
\hline 14 & $84.5 \%$ & $94.83 \%$ & $94.59 \%$ & $96.63 \%$ \\
\hline 16 & $88.58 \%$ & $96.97 \%$ & $97.04 \%$ & $98.55 \%$ \\
\hline 18 & $93.62 \%$ & $98.31 \%$ & $100 \%$ & $100 \%$ \\
\hline 20 & $95.26 \%$ & $100 \%$ & $100 \%$ & $100 \%$ \\
\hline 21 & $100 \%$ & $100 \%$ & $100 \%$ & $100 \%$ \\
\hline
\end{tabular}

Average Wound Area (sq.m m)

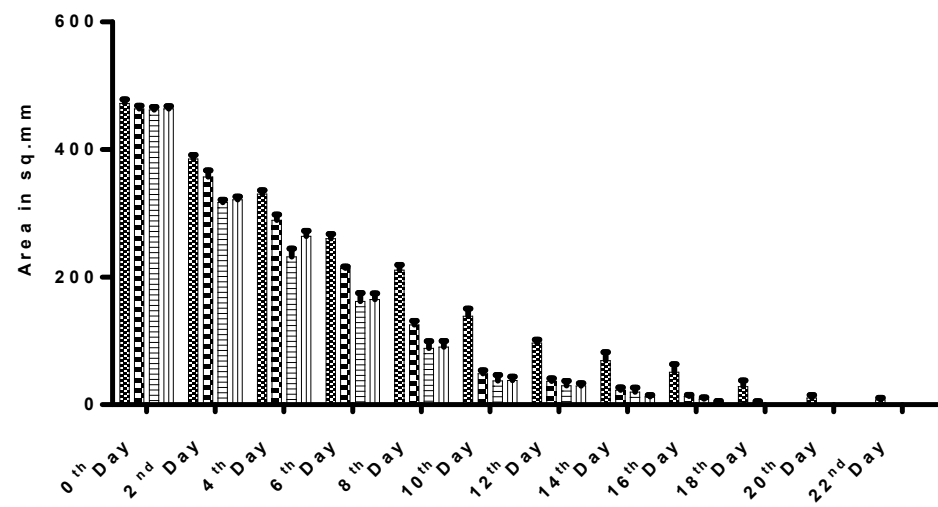

\[ \text { Group I } \]
$=$ Group II
$=$ group III
Group IV

Figure 1: Effect of AESE on wound area (sq.mm) in Excision Wound Model

Table 6: Effect of leaf extract of S.erianthum on wound breaking strength (g) in incision wounds

\begin{tabular}{|c|c|c|}
\hline Groups & Treatment & Wound Breaking Strength (g) \\
\hline Group I & -- & $268.0 \pm 7.5$ \\
\hline Group II & $5 \%$ w/w Povidone-Iodine & $368.9 \pm 14.51^{* * *}$ \\
\hline Group III & $10 \%$ AESE & $417.9 \pm 12.23^{* * *}$ \\
\hline Group IV & $20 \%$ AESE & $483.8 \pm 11.0^{* * * *}$ \\
\hline
\end{tabular}

Values are mean \pm SEM $(n-6)$ one way ANOVA followed by Dunnet's test where * represents significant at $<0.05$,

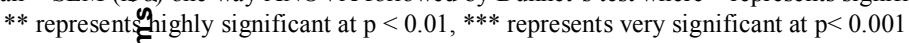

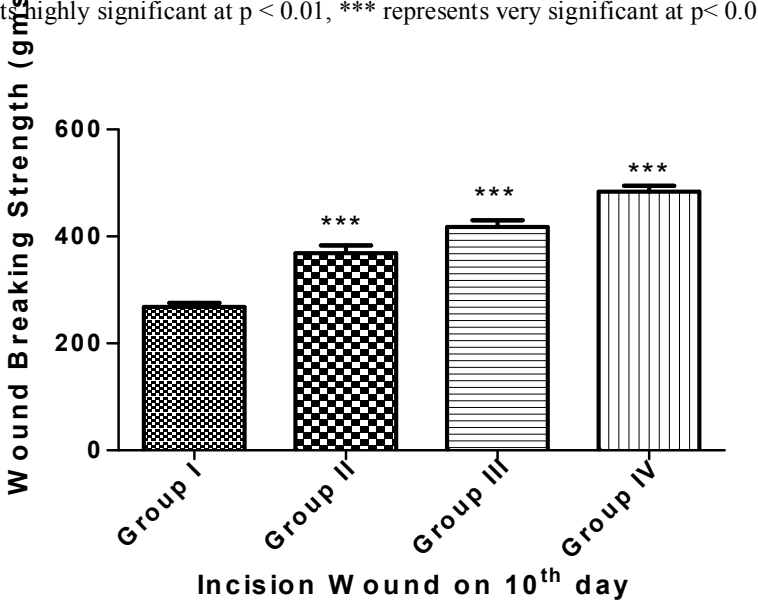

Figure 2: Effect of AESE on Breaking Strength (g) in Incision Wound Model 

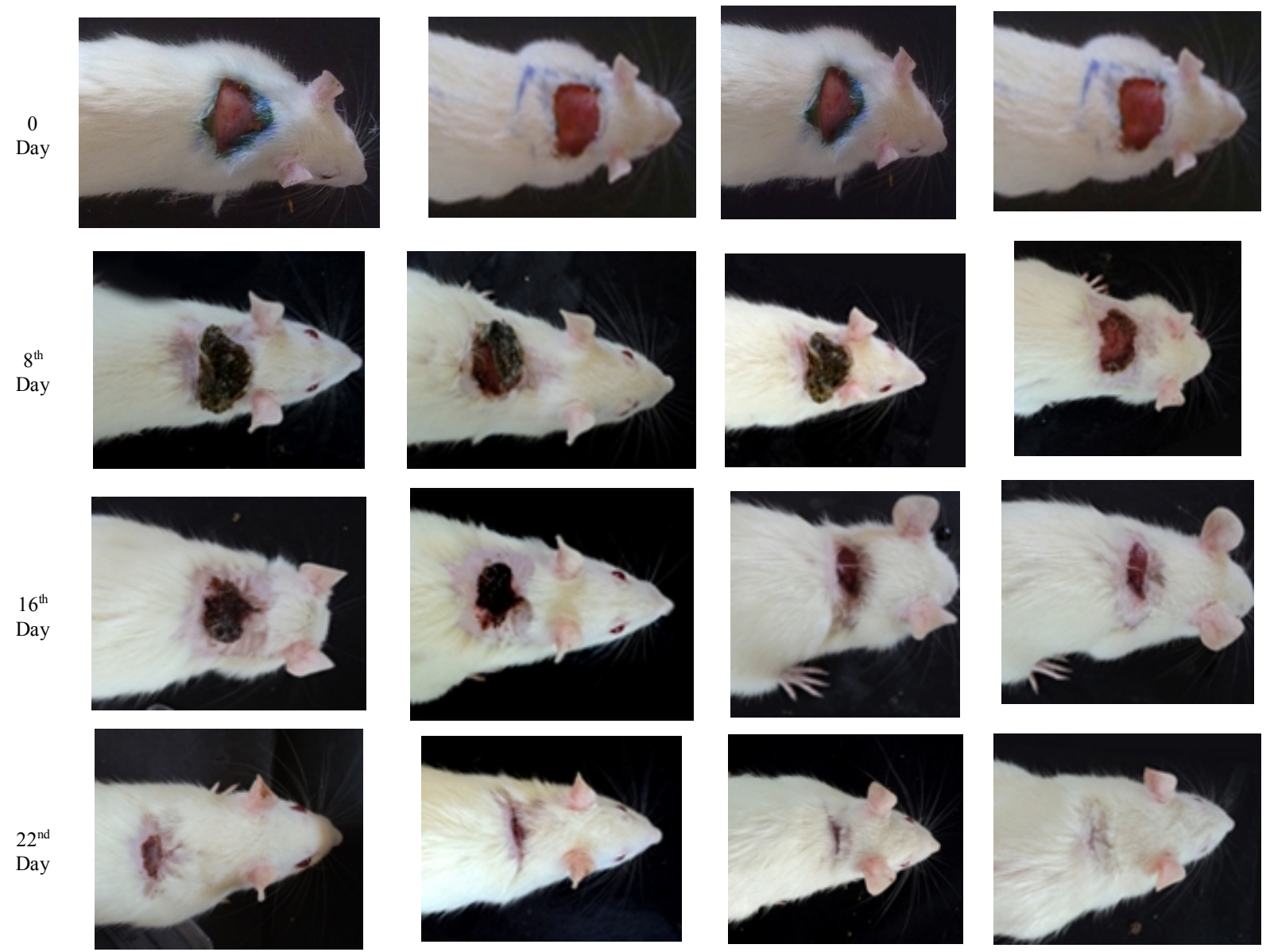

CONTROL

POVIDONE-IODINE

$10 \%$ AESE

$20 \% \mathrm{AESE}$ NOTE: Significant decrease in wound area in $20 \%$ AESE and $10 \%$ AESE

Figure 3: Photographs showing excision wound (topically treated) at different days
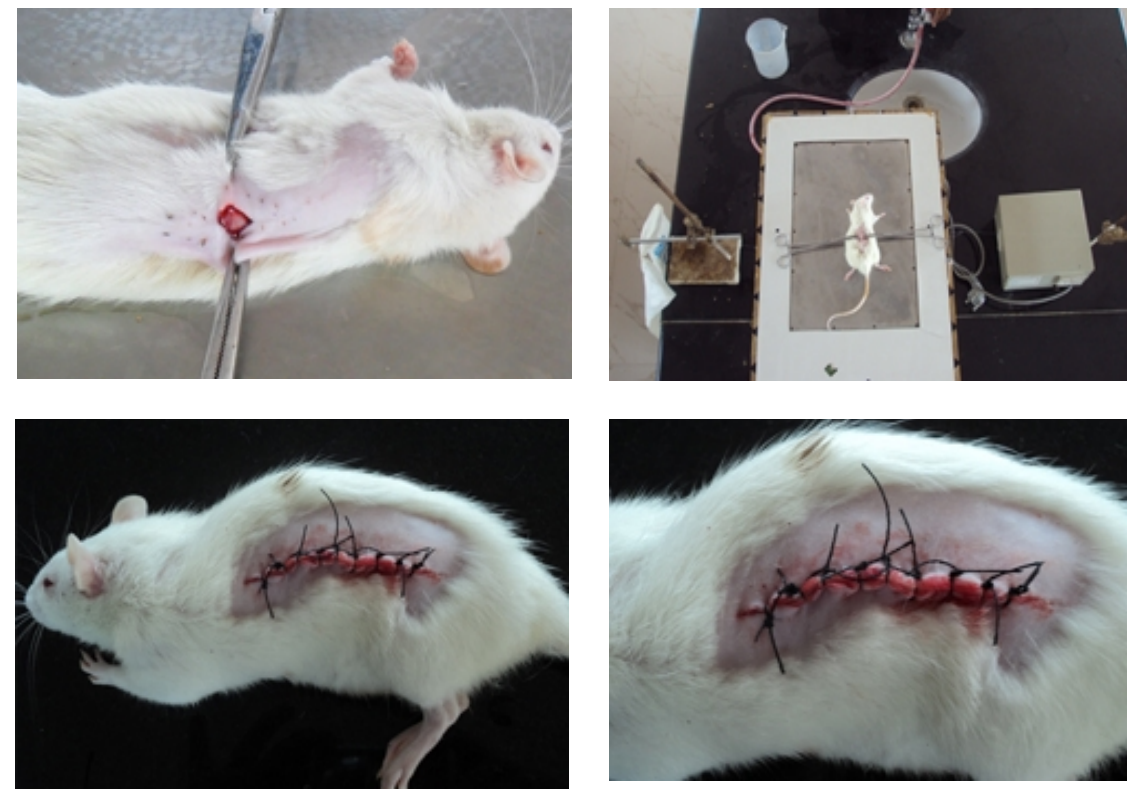

Resutured incision wound

Figure 4: Tensile strength measurement and setup for its measurement 


\section{DISCUSSION}

The present study was undertaken to evaluate whether Solanum erianthum leaf extract could promote wound healing in experimentally produced wound in rats. This observation substantiates the use of Solanum erianthum leaves in folklore medicine for the treatment of wounds. The preliminary phytochemical analysis of AESE revealed the presence of flavonoids, alkaloids, tannins, steroids, glycosides, carbohydrates and proteins.

In the present study, the extract applied topically promoted the breaking strength, the wound contraction and period of epitheliazation.

The skin irritation study on the rabbit skin proved that drug does not show any type of inflammation when applied to the skin. This suggests that the drug may contain some chemical constituents, which does not produce any irritation and navigate the wound healing activity of Solanum erianthum.

In excision wound model the AESE showed faster healing compared with control groups and wound contraction rate was faster. It may be due to stimulation of interlukin-8. The epitheliazation period was decreased may be due to enhanced collagen synthesis.

In incision model, the wound breaking strength was increased. Increase in tensile strength may be due to increase in collagen concentration and stabilization of the fibres.

Flavonoids are known to reduce lipid peroxidation, not only by preventing or slowing the onset of cell necrosis but also by improving vascularity. Hence any drug that inhibits lipid peroxidation is believed to increase the viability of collagen fibres, increasing the circulation, preventing the cell damage and by promoting the DNA synthesis.

AESE contains alkaloids, which are used internally to treat stomach-ache and is applied externally to skin irritations and rashes.

Solanum erianthum was more potent than Povidone Iodine in excision and incision wound models.

\section{REFERENCES}

1. Nagappa AN, Cheriyan B. Wound healing activity of the aqueous extract of Thespesia populnea fruit. Fitoterapia 2001; 72:503-506. http://dx.doi.org/10.1016/S0367-326X(01)00275-1

2. Blomqvist MM, Nguyen Tien Ban, et al. Plant Resources of SouthEast Asia. Medicinal and poisonous plants. Prosea Foundation, 2nd edition, Bogor, Indonesia. 2009. p. 453-458.
3. The wealth of India -A dictionary of Indian raw materials and industrial production. 2nd edition, Vol-9, New Delhi, CSIR, 1972. p.380.

4. Krishna Marg KS. The useful plants of India. 1st edition. New Delhi: Publication and Information directorate CSIR; 1992. p. 579580 .

5. Yoganarsimhan SN. Medicinal Plants of India. 3rd edition Volume-1. Bangalore: Interline Publishing Ltd; 1996. p. 435.

6. Huang ST, Su YJ, Chien DK, Li EJ, Chang WH. Solanum erianthum intoxication mimicking an acute cerebrovascular disease. The Am J Emer Med. 2009; 27 (2): 249-249. http://dx.doi.org/ 10.1016/i.ajem.2008.05.026

7. Kakali saha, Pulok Mukherjee K, Das J, Pal M, Saha B P. Wound healing activity of leucas lavandulaefolia Rees. J Ethanopharmacol. 1997; 56:139-144. http://dx.doi.org/10.1016/S0378-8741(97)01522$\underline{5}$

8. Naira Nayeem, Karvekar. A review of wound healing. Int J Appli Biol Pharmaceu Tech. 2010; 1 (3):1369-1377.

9. Chaitali shah. A text book of pathology notes. 2nd edition. Mumbai: Bhalein Publishing House; 1993. p. 52-54.

10. Anne Waugh, Allison grant. Anatomy and physiology in health \& illness.Ross and Wilson. 9thEdition. 2001. 367-368.

11. Kokate CK, Khandelwal KR, Pawar AP, Gohale SB. Practical Pharmacognosy. Nirali Prakashan, Pune, 3rd Edition. 1995, p-137139

12. Singh SDJ, Krishna V, Mankani KL, Manjunatha BK, Vidya SM, Manohara YN Wound healing activity of the leaf extracts and deoxyelephantopin isolated from Elephantopus scaber Linn. Indian J Pharmacol 2005; 37: 238-242. http://dx.doi.org/10.4103/02537613.16570

13. Feller G, Kobel W, Seifert G. Overview of animal test method from skin irritation. Food chem. Toxicol 1985; 23(2): 165-8. http:// dx.doi.org/10.1016/0278-6915(85)90009-2

14. Kuppast IJ, Kusums Akki, Prasannav Gudi, Hukkeri VI. Wound healing activity of Polianthes tuberoso bulb extracts Indian J Nat Prod 2003; 22(2): 10.

15. Morton JJP, Malone HH Evaluation of vulnerary activity by open wound procedure in rats, Arch Int Pharmacodyn 1972; 196: 117

16. Ehrich HP, Hunk TK. Effect of cortisone and anabolic steroids on tensile strength of healing wound. Ann Surg 1969; 170:203-6. http://dx.doi.org/10.1097/00000658-196908000-00007

17. Silambujanaki P, Bala tejo Chandra $\mathrm{CH}$, Anil Kumar K and Chitra V. Wound healing activity of Glycosmis arbora leaf extract in rats. J Ethanopharmacol 2011; 134: 198-201. http://dx.doi.org/10.1016 /j.jep.2010.11.046 PMid:21129469

18. Chimkode R, Patil M B, Sunil S, Reddy patil N, Nitin Agarwal, Ashish Tripathi. Wound healing activities of leaves of Andrographis paniculata Burm.F. Int J Pharmacol Biol Sci 2008; 2 (3); 153-156.

19. Sudha Bhargavi CH, Vrushabendra Swamy et al. Effect of Solanum erianthum.D.Don leaves on burn wound healing in wistar rats. Pharmanest. 2012; 3(4): 152-158.

Cite this article as:

Ch. Sudha Bhargavi, Vrushabendra Swamy, Syed Bilal, Ushasri S, Ranjith Kumar J. Wound healing activity of alcoholic extract of Solanum erianthum D.Don in excision and incision method. Int. J. Res. Ayur. Pharm. 2013; 4(1):130-135 